AJIM

70,6

Received 30 May 2018 Revised 10 September 2018 28 September 2018 3 October 2018 Accepted 3 October 2018

\title{
Are book publications disappearing from scholarly communication in the social sciences and humanities?
}

\author{
Tim C.E. Engels \\ University of Antwerp, Antwerp, Belgium \\ Andreja Istenič Starčič \\ University of Ljubljana, Ljubljana, Slovenia; \\ University of Primorska, Koper, Slovenia and \\ Kazan Federal University, Kazan, Russia \\ Emanuel Kulczycki \\ Adam Mickiewicz University in Poznan, Poznan, Poland \\ Janne Pölönen \\ Federation of Finnish Learned Societies, Helsinki, Finland, and \\ Gunnar Sivertsen \\ Nordic Institute for Studies in Innovation, Research and Education, Oslo, Norway
}

\begin{abstract}
Purpose - The purpose of this paper is to analyze the evolution in terms of shares of scholarly book publications in the social sciences and humanities (SSH) in five European countries, i.e. Flanders (Belgium), Finland, Norway, Poland and Slovenia. In addition to aggregate results for the whole of the social sciences and the humanities, the authors focus on two well-established fields, namely, economics \& business and history.

Design/methodology/approach - Comprehensive coverage databases of SSH scholarly output have been set up in Flanders (VABB-SHW), Finland (VIRTA), Norway (NSI), Poland (PBN) and Slovenia (COBISS). These systems allow to trace the shares of monographs and book chapters among the total volume of scholarly publications in each of these countries.

Findings - As expected, the shares of scholarly monographs and book chapters in the humanities and in the social sciences differ considerably between fields of science and between the five countries studied. In economics \& business and in history, the results show similar field-based variations as well as country variations. Most year-to-year and overall variation is rather limited. The data presented illustrate that book publishing is not disappearing from an SSH.

Research limitations/implications - The results presented in this paper illustrate that the polish scholarly evaluation system has influenced scholarly publication patterns considerably, while in the other countries the variations are manifested only slightly. The authors conclude that generalizations like "performance-based research funding systems (PRFS) are bad for book publishing" are flawed. Research evaluation systems need to take book publishing fully into account because of the crucial epistemic and social roles it serves in an $\mathrm{SSH}$.
\end{abstract}

Originality/value - The authors present data on monographs and book chapters from five comprehensive coverage databases in Europe and analyze the data in view of the debates regarding the perceived

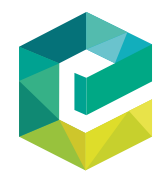

Aslib Journal of Information Management

Vol. 70 No. 6,2018 pp. $592-607$ Emerald Publishing Limited 2050-3806 DOI 10.1108/AJIM-05-2018-0127
(C) Tim C.E. Engels, Andreja Istenič Starčič, Emanuel Kulczycki, Janne Pölönen and Gunnar Sivertsen. Published by Emerald Publishing Limited. This article is published under the Creative Commons Attribution (CC BY 4.0) licence. Anyone may reproduce, distribute, translate and create derivative works of this article (for both commercial and non-commercial purposes), subject to full attribution to the original publication and authors. The full terms of this licence may be seen at $\mathrm{http} / / /$ creativecommons.org/licences/by/4.0/legalcode

This work is conducted within the framework of the COST action "European Network for Research Evaluation in the Social Sciences and Humanities" (ENRESSH, CA15137, enressh.eu). Tim Engels thanks the Flemish Government for its financial support to the Centre for R\&D Monitoring (ECOOM). 
detrimental effects of research evaluation systems on scholarly book publishing. The authors show that there is little reason to suspect a dramatic decline of scholarly book publishing in an SSH.

Keywords Humanities, Social sciences, Book chapter, Book publishing, Monograph,

Performance-based research funding

Paper type Research paper

\section{Introduction}

Publication patterns in the social sciences and humanities (SSH) are diverse. In the SSH book communication publishing takes a prominent role, both in terms of communicating with international peers and with a broader intelligentsia (Basili and Lanzillo, 2018; Hicks, 2004; Verleysen and Engels, 2014). Nevertheless, many criticisms of scholarly book publishing have been voiced. Harnad (1986), for example, advised against contributing chapters to edited volumes given the long delays that may occur in their publication process. Nederman (2005) warns that in academic evaluation contexts book chapters and edited volumes are hardly taken into account. In some humanities disciplines, however, the publication of a scholarly monograph is a requirement for professors to obtain tenure (Cronin and La Barre, 2004). In the field of history, for example, the publication of a monograph is considered a test of competency and of prestige, and a necessity in order to obtain tenure in the USA (Townsend, 2003). Yet the immanent disappearance of the scholarly monograph has also been predicted (Thompson, 2002) and has been attributed to research evaluation regimes (Williams et al., 2009). In sum, there is no shortage in opinions on the evolving role and position of books in the SSH and the factors influencing these evolutions. Systematic empirical information regarding the share of monographs and book chapters among scholarly publications is scantly available, however, thus complicating the interpretation of perceived evolutions, if any.

We fill this gap in the research literature by investigating empirically the evolutions of the shares of scholarly book publications using comprehensive publication data collected in Flanders (Belgium), Finland, Norway, Poland and Slovenia. For each country, we analyze the evolution of the share of monographs and book chapters for the humanities and the social sciences. Moreover, we analyze this evolution for the field of history within the humanities and for the field of economics \& business within the social sciences. We discuss the implications of the empirical observations in relation to the often voiced concern that formal research evaluation regimes work against the production of books.

The structure of this paper is as follows. First, the literature review discusses factors that may influence SSH scholars in their choice of publication channels, and some of the available evidence regarding the evolving share of book publications among scholarly publishing. After the methods and data section, we present the results in a series of eight tables. The discussion summarizes the empirical findings and positions them in the light of the debate on the possible consequences of research evaluation regimes.

\section{Literature review}

Several factors may influence the choices of an SSH scholars to publish chapters, edited volumes or embark on a monograph. We distinguish between factors relating to the research process itself, factors relating to the process of publication, factors relating to the findability and visibility of publications and factors relating to informal and formal academic evaluation contexts.

\section{Research process}

With regard to the research process, the epistemic approach in the humanities and parts of the social sciences may be a fundamental reason for scholars to opt for book publications. For instance, Bonaccorsi (2018) argues that book publications are compatible with an SSH scholars' need for long explanations, and Basili and Lanzillo (2018) suggest that monographs 
AJIM 70,6 in particular allow scholars to establish and affirm their ideas. Similar arguments have led Crossik (2016) to emphasize the central position of the monograph in the culture and ecology in the humanities and most of the social sciences, and Bonaccorsi (2018) to state the books are the most important source in the SSH. Qualitative research by Hammarfelt (2017) illustrates the prestige of monographs in the field of history, and the commonness of book chapters in both history and economics. Similarly, Edwards (2012) argues that edited volumes allow for authoritative comparative perspectives across time, geographic localities and disciplinary borders. Reinforcing earlier arguments by Nederman (2005), she also emphasizes that edited volumes serve to establish scholarly communities, a process that is tightly linked to the research process itself. Cronin (2003), however, argues that there is no in-principle reason for scholars to not leave the monograph behind and move to a collection of journal articles and/or other formats. Thus, book publications and journal articles may not be so much opposed to each other, but the preference for one or the other rather be nurtured through scholarly cultures, and structural and demographic factors (Wolfe, 1990).

Recent empirical work shows that book publishing and journal publishing supplement each other rather than represent alternatives in the SSH (Sivertsen, 2016; Verleysen and Engels, 2012; Verleysen and Ossenblok, 2017; Verleysen and Weeren, 2016). Monographs, edited volumes and the chapters therein and journal articles represent different scholarly approaches that may all need to be used at different times. Williams et al. (2018), for example, report a preference of junior Italian authors for journal articles, while more established authors embark more often on book length publications. How such tendencies will evolve in increasingly digital and interdisciplinary environments, with digital humanities, large data sets and collaboration involving multiple disciplines becoming ubiquitous, is difficult to assess.

Traditionally, the SSH have been characterized as less focused on discoveries and much less cumulative in knowledge development then science, technology, engineering and medicine (STEM) fields, leading to fragmented competition within a certain paradigm (Bonaccorsi, 2018). However, the gradual evolution of disciplines such as archaeology (Jones, 2008) and art studies (Lewandowska and Miroslaw Stano, 2018) into fields where many of the important breakthroughs are possible thanks to interdisciplinary collaboration, and the evolution of fields such as communication studies, economics \& business, education, history, linguistics, literature, political science and sociology into fields that work ever more with digital data and techniques, might gradually introduce more of the across the board competition that is characteristic of the STEM journal landscape. Priority in publishing an analysis and results for example becomes more important with digital data sets, especially when they are available as the FAIR data. Moreover, such interdisciplinary and data intense collaborations often imply more co-authors, each with their own views and expectations with regard to publishing the results.

In sum, even though epistemic cultures may encourage book publishing, the gradual transformations of some specialisms and even whole disciplines into digitally driven and interdisciplinary scholarship may result in book publishing becoming less evident. This may be the case for publishing monographs if relatively less researchers work on their own, as well as for edited volumes and book chapters because the timelines need to coincide with those of collaborators.

\section{Publication process}

In terms of publication process, the delay that may occur when publishing edited volumes or book chapters therein may be a reason for avoiding such publications. Indeed, a survey by Williams et al. (2018) reports that the preference of junior authors for journal articles is motivated by the speed of publication, as well as the formal peer review process. Delays in publication may be even more prominent for monographs, as one or a few authors take on the entire working load whereas in the case of edited volumes the workload is more distributed (Edwards, 2012). The technological transformation from print to digital has also been 
identified as a factor for the decline in book publishing (Elliot, 2015; Joseph, 2015), even though with e-publishing the publishing process of some volumes is now rather similar to that of many journals. Moreover, self-publishing and printing on demand may stimulate book publishing. Indeed, even though market consolidation for academic book publishing has been reported (Thompson, 2005), book publishing is still a more open market then the journal publishing industry, i.e. with less dominance of a few big players (Guns, 2018; Larivière et al., 2015). For the SSH, with paradigmatic pluralism present in most disciplines (Bonaccorsi, 2018), such an open market for book publishing probably stimulates book publishing, whereas the hegemony of a few big players in the journal publishing industry may be a gateway for the publishing of articles that follow mainstream or uncontested paradigms.

\section{Findability and visibility of publications}

In terms of findability and visibility of publications, the fact that most books still appear as physical entities only puts book publishing at a disadvantage compared to journal publishing, where most articles appear as digital entities (too). Digital entities are often easier to find, which may be an important factor in an era of increasing internationalization. Especially in the case of open access publishing, digital entities become also more accessible and, hence, can reach a broader, and global, audience. e-books have these characteristics too yet represent only a relatively small share of scholarly book publishing. Options for open access publishing and self-archiving with reasonable embargo periods are often more limited for book publications than journal articles. Moreover, books are often not indexed in international systems, especially citation indexes. Indeed, even in the most advanced global systems like CrossRef, Microsoft Academic or Google Scholar citations to and from books seem hard to trace, and Google Books is not fully integrated into Google Scholar (Donner, 2018).

In addition to the aforementioned factors relating to findability and visibility among scholars, findability and visibility for a broader public can be driving force for book publishing. Indeed, much scholarly book publishing is not solely focused on an academic audience and serves an explicit enlightenment role (Hicks, 2004). In the field of history, for example, book publishing is closely intertwined with the aim of reaching a broader audience (Zuccala et al., 2015). More often than not such books are written in a local language rather than in English. Within the target region of the scholar, the findability (e.g. in book shops and libraries) and visibility (e.g. through coverage in local media) of such books is often high.

\section{Academic evaluation contexts}

In academic evaluation contexts, book publishing has had different statuses, with monographs requirements on the one hand and negligence of edited volumes on the other hand. This may gradually be changing, with the requirement for a monograph becoming less common in the humanities (e.g. both with regard to the format of $\mathrm{PhD}$ theses and in view of obtaining tenure). Evaluation cycles may influence scholars' decisions (not) to embark on a monograph project, e.g. when the envisioned time needed for completion is more than the interval between two evaluations (Williams et al., 2009). Moreover, the weights for scholarly book publications and journal articles can shape how authors perceive the value of a given publication type. For instance, since 1999, scholarly book publications in Poland have been assigned lower weights than journal articles in the Polish research evaluation system. Hence, publishing articles is a more efficient strategy for Polish scholars (Kulczycki, 2017). In Slovenia, growth of international publications was accompanied by growth of scientific monographs in Slovenian in the period from 1998 to 2005 (Sorčan et al., 2008). Sorčan et al. (2008) attribute this to importance of monographs for the national development of a scholarly field. According to an interview study of Finnish SSH professors, a (real or perceived) decline of the share of monographs may also be linked to universities' recruitment policies that gradually placed more weight on peer-reviewed articles in international journals (Puuska, 2014). Indeed, the 
AJIM

70,6

aforementioned study by Williams et al. (2018) illustrates that younger scholars in particular may value the transparency of the journal publishing system. It is also a relatively widely held conviction among the Finnish SSH research community that research policy in general, and performance-based research funding systems (PRFS) in particular, favors English language journal articles (Sivula et al., 2015). This is the case even though books and national language publications are taken into account in the national quality index of peer-reviewed publication channels supporting the PRFS (Pihlström, 2014). Contrary to Norway and Denmark, Finland has also weighted book chapters and journal articles equally in its PRFS. Moreover, several PRFS make peer review of book publications explicit through lists of book publishers, book series, peer review labels and listing of peer reviewers (Gimenez-Toledo et al., 2016, 2018). Still, the claim that informal and formal academic evaluation contexts and processes hamper book publishing resonates well (e.g. Hammarfelt and de Rijcke, 2015). We will therefore discuss our findings in particular in relation to such claims.

Overall, we observe drivers that may cause book publishing to increase as well as drivers for book publishing to become less common. We have, therefore, decided: to investigate empirically the evolutions in terms of shares of book publishing in the humanities and in the social sciences in five European countries, and to analyze this evolution also specifically for two well-established fields, i.e. history as a field within the humanities, and economics \& business as a field within the social sciences.

\section{Empirical studies regarding the evolution of the share of scholarly book publications}

Empirical evidence regarding the evolution of the share of scholarly book publications in the total volume of scholarly publications in a given country is rare. The main reason lies in the fact that in most countries comprehensive coverage data are not readily available. Norway pioneered a trend toward establishing comprehensive coverage databases, which identify those book publications that are peer-reviewed explicitly (Sīle et al., 2017). Yet even where full coverage national publication databases are in place, several of them do not include edited volumes as a publication type that may be peer reviewed (Kulczycki et al., 2018). This is for example the case in most Nordic countries, for which a sizable share of monographs (4.9 percent) and book chapters (29.5 percent) among the SSH publications 2015 has been reported (Nordforsk, 2018). As such, the evolution of the share of book publications in the total volume of scholarly publications remains difficult to study, especially over longer time spans. What empirical evidence is available points to different evolutions. Engels et al. (2012) reported a stable share of book publications for the humanities for the years from 2000 to 2009, a period during which book publications were not taken into account in the regional Flemish performance-based funding system. For the social sciences, however, they reported a smaller and falling share of book publications. Aagaard et al's (2015) report stability in the publication patterns of Norway in an evaluation of the effects of the Norwegian publication indicator for performance-based research funding for institutions. Sivertsen (2016) finds the same, but journal publishing is more abundant among younger researchers. In Finland, there are indications based on data from selected universities that the importance of scholarly book publishing in an SSH fields did not diminish in the years 1997-2008. Due to differences in definitions, the shares are not directly comparable with the data used in this study (Puuska 2011; Puuska, 2014). For Slovenia, Sorčan et al. (2008) reported a 60 percent increase of the share of monographs in Slovenian in the period 1998-2005. In Poland, the share of scholarly book publications decreased substantially in the years 2009-2016, probably due to changes in the Polish research evaluation model (Kulczycki, 2018). However, interpreting these changes in book patterns, one needs to take into account that definitions of scholarly book types changed during this period too. In a comparison of data for eight countries, Kulczycki et al. (2018) report, for the period 2011-2014 and a selection of disciplines including economics \& business, stable shares of monographs and book chapters for some countries (Denmark, Flanders and Norway), 
potentially declining shares for others (Finland and Slovenia) and considerable year-to-year variations for yet other countries (the Czech Republic and Poland). We here expand the Kulczycki et al. (2018) study to the whole of the humanities and the social sciences and, in particular, to all years for which comprehensive data are available in each of our countries.

In sum this study analyses the comprehensive coverage data on the share of peer-reviewed book publications (book chapters, edited volumes and monographs) that are available from Flanders and Slovenia for the period from 2004 to 2015. We supplement these data with data on peer-reviewed book chapters and monographs from Norway for the period from 2005 to 2015 as well as data on all types of peer-reviewed book publishing for the period from 2009 to 2014 for Poland and 2011 to 2015 for Finland. This approach allows us to shed light on the share of book chapters and monographs in humanities and in social sciences in five different countries from Central, Northern, Southern and Western Europe, and to compare these shares and their trends across countries. Moreover, we analyze the same trends for the disciplines of history and economics \& business, two well-established disciplines with a sizeable presence in each of the five countries. This approach allows us to further the understanding of the overall trends for humanities and social sciences, without assuming, however, that either history or economics \& business are somehow representative of humanities, respectively, social sciences.

\section{Data and methods}

Data for this paper were collected from five comprehensive coverage national publication databases. For recent detailed and comparative descriptions of these databases (namely the VABB-SHW or Flemish Academic Bibliographic database for SSH in Flanders, the VIRTA information publication service in Finland, the Norwegian Science Index in Norway, the Polish Scholarly Bibliography in Poland and the Cooperative Online Bibliographic System and Services in Slovenia), we refer to Sīle et al. (2017, 2018) and Kulczycki et al. (2018). For VABB-SHW (Guns et al., 2018), VIRTA and NSI all publications are classified according to the OECD fields of science classification (Organisation for Economic Co-operation and Development, 2015) and, hence reported as such. For the Polish PSB, the organizational classification of publications allows reporting of overall numbers for SSH, social sciences, humanities, as well as economics \& business, law and history. In the case of Slovenia, the classification of publications in COBISS according to the Universal Decimal Classification system was translated toward the OECD Fields of Science.

Clearly, each of the databases uses either its own classification system (COBISS and PSB), or a local implementation of the OECD-FoS classification (NSI, VABB-SHW and VIRTA). Thus, the classification of publications into disciplines and fields is not uniform across the five databases. Similarly the way the requirement of peer review is implemented differs across countries, as do other factors such as the definitions of publication types, the data collection processes, the (potential) impact of (not) reporting publications, etc. Thus, differences in terms of the shares presented per country should not be taken as exact representations of the position of scholarly book publishing between the countries. Rather, the time trends per country are illustrative of the evolving position of scholarly book publishing per country. Differences between countries can be understood as general trends only.

A total of 336.681 peer-reviewed publications (each publication wholly counted at national level) are taken into account for this study. For Flanders, 48.200 publications published between 2004 and 2015, among which 73.8 percent journal articles and contributions to proceedings, 2.0 percent monographs, 3.7 percent edited volumes and 20.5 percent book chapters are included in this study. For Slovenia, the total number of publications 2004-2015 amounts to 92.522, among which 63.8 percent journal articles and contributions to proceedings, 4.8 percent monographs, 9.4 percent edited volumes and 22.0 percent book chapters. In the case of Poland, the total number of publications (2009-2014) is 128.275, including 26.4 percent journal articles and contributions to proceedings, 10.6 percent 
AJIM 70,6

598

monographs, 7.1 percent edited volumes and 55.8 percent book chapters. In Finland for the years from 2011 to 2015 , we count 40.057 publications, including 59.2 percent journal articles and contributions to proceedings, 3.8 percent monographs, 5.8 percent edited volumes and 31.1 percent chapters in books. Norway contributes with 27.627 publications from 2005 to 2015, of which 57.7 percent are journal articles, 38.0 percent are chapters in books and 4.3 percent are monographs. The assignment of publications to the OECD-FoS level 2 fields History and economics \& business is available in the NSI for the period 2011-2015 only.

For the field of history, a subset of 30.893 peer-reviewed publications is taken into account. 3.103 of these publications stem from Flanders, 3.424 from Finland, 1.449 from Norway, 17.395 from Poland and 5.522 from Slovenia. Overall, 34.0 percent of these history publications are journal articles and contributions to proceedings, 9.5 percent monographs, 7.4 percent edited volumes and 49.1 percent book chapters. In the OECD-FoS classification, history and archaeology are grouped together, whereas here we attempted at considering History separately. For Flanders and Slovenia History and Archaeology are indeed separated from each other. For Finland and Norway this is not the case, whereas for Poland most archaeology units seem to be classified under history even though ion the Polish organizational classification system archaeology is considered a separate field. For the three latter countries for which we consider a shorter time window (2011-2015 and 2009-2014, respectively) the numbers and shares presented in this paper thus pertain, at east to some extent, to history and archaeology together.

For the field of economics \& business a subset of 52.897 peer-reviewed publications is taken into account. In total, 5.735 of these publications stem from Flanders, 1.820 from Finland, 1.654 from Norway, 28.152 from Poland and 15.536 from Slovenia. Overall, 52.5 percent of these economics \& business publications are journal articles and contributions to proceedings, 6.3 percent monographs, 6.8 percent edited volumes and 34.5 percent book chapters.

\section{Results}

We here present results for the share of monographs and the share of book chapters for the humanities, for the field of history, for the social sciences and for the field of economics \& business. In the tables below, shares are presented as they are calculated in the different national systems, meaning that for Norway the sum of the share of articles in journals and proceedings, book chapters and monographs is 100 percent, whereas in the four other countries the share of peer-reviewed edited volumes needs to be added in order to get the full picture.

\section{Humanities}

Table I presents the share of monographs in the humanities per year per country. Similarly, Table II presents the share of book chapters in the humanities per year per country. For the

Table I.

Share of monographs in the humanities

\begin{tabular}{cccccc}
\hline Year & Flanders & Finland & Norway & Poland & Slovenia \\
\hline 2004 & 2.6 & & & & 8.2 \\
2005 & 3.0 & & 4.7 & & 6.7 \\
2006 & 3.4 & 5.6 & & 5.9 \\
2007 & 3.4 & & 4.7 & & 6.1 \\
2008 & 3.8 & & 5.9 & 13.9 & 6.5 \\
2009 & 2.3 & 5.1 & 13.5 & 5.6 \\
2010 & 3.1 & & 5.4 & 14.3 & 6.4 \\
2011 & 3.2 & 4.6 & 3.8 & 15.4 & 6.6 \\
2012 & 3.6 & 4.2 & 5.3 & 5.7 & 7.7 \\
2013 & 2.4 & 4.3 & 4.5 & 6.0 & 6.1 \\
2014 & 3.0 & 4.0 & 3.8 & & 7.2 \\
2015 & 2.5 & 4.9 & & &
\end{tabular}




\begin{tabular}{|c|c|c|c|c|c|c|}
\hline Year & Flanders & Finland & Norway & Poland & Slovenia & $\begin{array}{l}\text { Scholarly } \\
\text { communication }\end{array}$ \\
\hline 2004 & 25.5 & & & & 21.5 & \\
\hline 2005 & 21.8 & & 43.2 & & 30.5 & \\
\hline 2006 & 24.0 & & 43.3 & & 31.6 & \\
\hline 2007 & 25.0 & & 44.7 & & 25.9 & \\
\hline 2008 & 25.2 & & 46.5 & & 23.5 & \\
\hline 2009 & 29.1 & & 40.4 & 58.1 & 32.2 & 599 \\
\hline 2010 & 30.0 & & 38.8 & 62.7 & 26.0 & \\
\hline 2011 & 29.5 & 43.5 & 39.0 & 59.0 & 33.4 & \\
\hline 2012 & 28.7 & 41.3 & 39.6 & 57.8 & 32.5 & Table \\
\hline 2013 & 34.4 & 47.0 & 40.9 & 48.7 & 30.0 & Share of bo \\
\hline 2014 & 30.3 & 40.2 & 40.8 & 47.6 & 26.9 & chapters in the \\
\hline 2015 & 28.0 & 38.0 & 37.9 & & 30.9 & humanities \\
\hline
\end{tabular}

period from 2004/2005 to 2015, the shares of both book chapters are rather stable in Flanders, Norway and Slovenia. The shares are also rather similar for Flanders and Slovenia, yet considerably higher in Norway. The share of monographs seems also rather stable in these three countries. Peer-reviewed monographs, however, make up less than 4 percent of the total number of peer-reviewed publications in the humanities in Flanders, around 5 percent in Norway and in most years considerably more than 5 percent in Slovenia. For the shorter time window 2011-2015, the shares in Finland seem rather stable for monographs and book chapters alike. The shares observed for Finland are similar to those for Norway. For Poland a sharp decrease in the share of monographs is manifest between 2012 and 2013, while the share of book chapters seems on a gradual decline since 2010 yet still at a comparatively high level. Overall, for humanities, the differences between countries in the height of the share of monographs seem the most striking observation.

\section{History}

For the field of history (Tables III and IV), we observe rather similar patterns than for the humanities as a whole. It should be noted, however, that somewhat more fluctuations are to be expected in the data for the field of history specifically as the population of researchers in history is much smaller than that of the whole of researchers in the humanities in each of the countries included in this study. Although monographs are

\begin{tabular}{|c|c|c|c|c|c|c|}
\hline Year & Flanders & Finland & Norway & Poland & Slovenia & \\
\hline 2004 & 4.1 & & & & 10.1 & \\
\hline 2005 & 1.7 & & & & 7.6 & \\
\hline 2006 & 1.7 & & & & 6.2 & \\
\hline 2007 & 2.9 & & & & 9.7 & \\
\hline 2008 & 2.3 & & & & 8.4 & \\
\hline 2009 & 2.9 & & & 13.4 & 6.3 & \\
\hline 2010 & 2.2 & & & 14.0 & 5.6 & \\
\hline 2011 & 1.2 & 5.7 & 11.3 & 14.3 & 4.4 & \\
\hline 2012 & 2.7 & 6.8 & 5.2 & 15.9 & 8.3 & \\
\hline 2013 & 0.7 & 4.6 & 8.6 & 5.8 & 8.1 & Table III. \\
\hline 2014 & 3.4 & 6.1 & 7.5 & 5.9 & 6.7 & Share of monographs \\
\hline 2015 & 3.0 & 8.0 & 8.6 & & 7.5 & in the field of history \\
\hline
\end{tabular}




\begin{tabular}{|c|c|c|c|c|c|c|}
\hline & & & & & & \\
\hline $\begin{array}{l}\text { Ajllvi } \\
706\end{array}$ & Year & Flanders & Finland & Norway & Poland & Slovenia \\
\hline & 2004 & 8.2 & & & & 22.4 \\
\hline & 2005 & 5.7 & & & & 52.3 \\
\hline & 2006 & 14.1 & & & & 44.1 \\
\hline & 2007 & 13.3 & & & & 16.0 \\
\hline & 2008 & 17.2 & & & & 25.6 \\
\hline 600 & 2009 & 18.8 & & & 63.4 & 28.6 \\
\hline & 2010 & 23.5 & & & 66.0 & 37.6 \\
\hline & 2011 & 25.1 & 59.7 & 39.9 & 61.6 & 36.8 \\
\hline Table IV. & 2012 & 27.3 & 50.8 & 47.4 & 58.1 & 26.7 \\
\hline Share of book & 2013 & 14.8 & 62.0 & 45.4 & 48.1 & 42.2 \\
\hline $\begin{array}{l}\text { chapters in the }\end{array}$ & 2014 & 22.7 & 50.6 & 61.8 & 45.9 & 32.3 \\
\hline field of history & 2015 & 20.2 & 41.3 & 46.0 & & 37.8 \\
\hline
\end{tabular}

generally considered very important in the field of history, the percentages of monographs published are close to those for the humanities as a whole. In Flanders, the share of monographs in History is slightly lower than for humanities as a whole, except for the last two years. For Poland and Slovenia, the shares of monographs are very similar for History and humanities as a whole, whereas for Finland and Norway the share of monographs in History is high compared to humanities as a whole. A similar pattern emerges for the share of book chapters, except for Slovenia where book chapters in History represent a considerably higher share of the total output than do book chapters in the whole of the humanities. An interesting observation in comparing the countries with each other is that in recent years Poland is no longer the country where the shares of monographs and book chapters are the highest among the five countries studied in this paper: Finland and Norway have higher shares in 2013 and 2014.

\section{Social sciences}

Table V presents the share of monographs in the social sciences per year per country. Similarly, Table VI presents the share of book chapters in the social sciences per year per country. We observe different trends per country and per publication type. In Slovenia, both the share of monographs and the share of book chapters seem stable over the whole 12 year period that we could study. For Flanders, the share of monographs seems stable although it is higher in the two most recent years, while the share of book chapters seems

\begin{tabular}{cccccc}
\hline Year & Flanders & Finland & Norway & Poland & Slovenia \\
\hline 2004 & 1.3 & & & & 4.0 \\
2005 & 1.2 & & 4.8 & & 4.1 \\
2006 & 1.2 & & 4.6 & & 3.9 \\
2007 & 1.1 & & 6.3 & & 4.3 \\
2008 & 1.7 & & 5.1 & 11.1 & 5.2 \\
2009 & 0.7 & & 3.5 & 11.5 & 4.3 \\
2010 & 1.1 & 4.6 & 2.6 & 11.9 & 5.2 \\
2011 & 1.9 & 4.4 & 2.4 & 12.0 & 4.7 \\
2012 & 1.6 & 3.0 & 2.5 & 5.6 & 5.3 \\
2013 & 1.6 & 2.9 & 2.6 & 5.0 & 4.1 \\
2014 & 2.1 & 2.7 & 2.1 & & 5.2 \\
2015 & 2.1 & & & &
\end{tabular}




\begin{tabular}{|c|c|c|c|c|c|c|}
\hline Year & Flanders & Finland & Norway & Poland & Slovenia & $\begin{array}{l}\text { Scholarly } \\
\text { communication }\end{array}$ \\
\hline 2004 & 12.9 & & & & 17.0 & \\
\hline 2005 & 9.1 & & 31.7 & & 18.9 & \\
\hline 2006 & 11.2 & & 31.2 & & 16.0 & \\
\hline 2007 & 11.5 & & 34.8 & & 17.4 & \\
\hline 2008 & 13.4 & & 34.6 & & 18.5 & \\
\hline 2009 & 16.4 & & 33.4 & 62.9 & 16.7 & 601 \\
\hline 2010 & 14.5 & & 32.7 & 65.9 & 18.1 & \\
\hline 2011 & 16.3 & 25.0 & 30.6 & 60.5 & 20.0 & \\
\hline 2012 & 17.5 & 27.3 & 33.9 & 55.6 & 17.6 & Table VI. \\
\hline 2013 & 19.5 & 23.6 & 33.0 & 42.2 & 17.5 & Share of book \\
\hline 2014 & 19.5 & 24.3 & 31.0 & 41.2 & 17.9 & chapters in the \\
\hline 2015 & 20.7 & 24.4 & 31.8 & & 19.6 & social sciences \\
\hline
\end{tabular}

consistently on the rise since the introduction of the Guaranteed Peer Reviewed Content (GPRC) (Verleysen and Engels, 2013) label. For Poland, the stark decline in the share of monographs between 2012 and 2013 is matched by a still remarkable yet much smaller decline in the share of book chapters around the same time. In Finland, the share of book chapters seems stable while the share of monographs has been declining gradually. A similar decline in the share of monographs in the total volume of peer-reviewed publications in the social sciences seems to have occurred in Norway a few years earlier. The share of book chapters seems stable in Norway at close to one in three publications in the social sciences. Overall, for the social sciences, the slight yet different trends between countries in the shares of monographs (stable in Slovenia, declining in Finland, Norway and Poland and possibly on the rise in Flanders) as well as book chapters (stable in Finland, Norway and Slovenia, declining in Poland and on the rise in Flanders) stand out most.

\section{Economics \& business}

Tables VII and VIII present, respectively, the share of monographs and of book chapters in economics \& business. As for the social sciences as a whole only for Poland large year-to-year variations are apparent. The shares of monographs and of book chapters are considerably lower than for the social sciences as a whole in Finland, Norway, and, to a lesser extent, Slovenia. For Flanders and Poland rather small differences only are apparent.

\begin{tabular}{|c|c|c|c|c|c|c|}
\hline Year & Flanders & Finland & Norway & Poland & Slovenia & \\
\hline 2004 & 3.6 & & & & 2.3 & \\
\hline 2005 & 3.0 & & & & 3.1 & \\
\hline 2006 & 2.4 & & & & 2.8 & \\
\hline 2007 & 2.0 & & & & 3.8 & \\
\hline 2008 & 1.9 & & & & 4.1 & \\
\hline 2009 & 1.0 & & & 9.3 & 4.2 & \\
\hline 2010 & 1.7 & & & 11.3 & 3.8 & \\
\hline 2011 & 1.2 & 2.4 & 1.0 & 12.6 & 4.5 & Table VII. \\
\hline 2012 & 1.5 & 3.1 & 1.3 & 11.1 & 2.8 & Share of monographs \\
\hline 2013 & 1.1 & 0.9 & 1.9 & 5.2 & 4.1 & in the field of \\
\hline 2014 & 2.5 & 1.2 & 2.0 & 4.1 & 3.3 & economics and \\
\hline 2015 & 1.3 & 0.8 & 1.2 & & 5.5 & business \\
\hline
\end{tabular}




\begin{tabular}{|c|c|c|c|c|c|c|}
\hline \multirow{6}{*}{$\begin{array}{l}\text { AJIM } \\
70,6\end{array}$} & Year & Flanders & Finland & Norway & Poland & Slovenia \\
\hline & 2004 & 17.3 & & & & 12.1 \\
\hline & 2005 & 13.7 & & & & 12.4 \\
\hline & 2006 & 11.3 & & & & 11.8 \\
\hline & 2007 & 16.2 & & & & $\begin{array}{l}11.0 \\
12.6\end{array}$ \\
\hline & 2008 & 16.9 & & & & 12.8 \\
\hline \multirow[t]{2}{*}{602} & 2009 & 21.7 & & & 62.8 & 6.8 \\
\hline & 2010 & 15.8 & & & 64.4 & 9.0 \\
\hline Table VIII. & 2011 & 16.3 & 10.8 & 22.4 & 56.1 & 11.7 \\
\hline & 2012 & 17.9 & 11.0 & 19.1 & 50.2 & 11.0 \\
\hline chapters in the field of & 2013 & 19.7 & 8.7 & 14.2 & 37.6 & 11.7 \\
\hline $\begin{array}{l}\text { economics and } \\
\text { endidid on }\end{array}$ & 2014 & 20.6 & 11.9 & 15.6 & 36.1 & 12.3 \\
\hline $\begin{array}{l}\text { business } \\
\text { butin }\end{array}$ & 2015 & 20.9 & 12.7 & 14.4 & & 13.8 \\
\hline
\end{tabular}

\section{Discussion}

In this paper, we examine the shares of monographs and of book chapters among peer-reviewed publications in the humanities and in the social sciences for Flanders (Belgium), Finland, Norway, Poland and Slovenia. We study the period 2004-2015, as this is the longest timespan for which comprehensive coverage publication data from at least two of the countries are available. In addition to the humanities and the social sciences as a whole, we study the share of monographs and of book chapters in the fields of history and of economics \& business.

The share of monographs among peer reviewed publications in the humanities seems stable in all countries except Poland. In the social sciences, the share of monographs among peer reviewed publications is at a lower base than in the humanities. Also, a gradual decline of the share of monographs in the social sciences seems to occur or have occurred in Finland and in Norway, whereas for Poland we again observe a sharp decline between 2012 and 2013. This sudden change in publication patterns in Poland can be linked to the reforms that were implemented in 2011 which changed the model of academic promotions in 2013 (Kulczycki et al., 2018). Self-publishing of monographs decreased after this reform because since then the Polish scholars can be promoted based on a series of articles rather than on the basis of a monograph only (Kulczycki, 2018). For Slovenia, the share of monographs in both humanities and in social sciences seems stable over the whole period 2004-2015. In Flanders, the share of monographs is the lowest among the five countries studied; in recent years, however, slight increases become apparent.

The share of book chapters in the humanities and in the social sciences seems stable in Finland, Norway and Slovenia. In Poland, we observe gradually declining shares of book chapters among the total volume of peer reviewed publications. In Flanders, the introduction of the GPRC label for peer reviewed books seems to have stimulated the publishing of book chapters, rather immediately in 2010 in the humanities and more gradually in the social sciences. The differences in the share of book chapters between countries remain large, with Norway and Poland at the higher end, Flanders and Slovenia at the lower end and with Finland holding a position in between the others. With the current longer term trends, the shares may gradually converge.

Before addressing some implications, a major limitation of this study needs to pointed out. Although in each of the five countries studied the same concepts are used, the actual definitions and implementations of what are peer reviewed publications, what are monographs, resp., book chapters and the OECD-FoS classification through which publications are assigned to fields are in all likelihood not identical. In fact the authors are aware of considerable differences implying that cross-country comparisons are not evident. 
At present, however, cross-country comparisons on the basis of data collected per country are the best possible option. Moreover, differences in measurement do not preclude comparisons in practice (Chang, 1997). A second limitation is that for Flanders and Slovenia only the whole period 2004-2015 could be studied. For Finland, Norway and Poland the available data concern shorter time spans.

These limitations notwithstanding, the data presented in this paper show that book publishing is not about to disappear from scholarly publishing in the SSH, nor from specific fields such as history and economics \& business. This conclusion holds for each of the five countries studied. In the light of the factors reviewed in the literature review this implies that no particular (set of) factor(s) appears as so dominant that it becomes decisive for the future of book publishing in the SSH. Indeed, as we pointed out in the literature review, the epistemic culture of most of the SSH makes it unlikely that book publishing would go away. This implies that publishers are right to continue their efforts to provide authors with opportunities to publish books, also in the digital era. Historians, for example, have been reported to be open to e-books (Martin and Quan-Haase, 2013). Also, the emergence of "short monographs," as launched through Palgrave Pivot and Routledge Focus, for example, may well sustain the share of monographs yet at the same time reduce the average length of the manuscripts. Edited volumes and the chapters that appear in them also serve important roles in scholarly community building, which makes them likely to remain important in the SSH. Publishers and scholars alike, however, are wise to pay close attention to the publishing process and its technological approach when embarking on book publications. The structured online visibility of the work to be published, including the open access, can influence the findability and visibility of the work to a great extent. Although currently this is mainly the case for the more academically oriented work, this will become crucial for book publications in local languages targeted toward a local intelligentsia. Several countries, e.g. Slovenia's National (2015) strategy of open access to scientific publications and research data already actively encourage open access to book publications.

Most importantly our analysis shows that academic research evaluation systems are by no means necessarily in conflict with book publishing. Such an observation contradicts the claims by Chodorow (1999), Williams et al. (2009) and others, who have argued that formal and informal evaluation systems work against book publishing, in particular in the humanities. Only in the case of Poland do we see a rather abrupt change in publishing patterns, away from book publishing. Thus, a negative impact on book publishing is possible, yet appears to be less likely in more mature evaluation systems. The case of Flanders illustrates that a formal PRFS aimed at distributing funding between universities and supplemented by formative evaluations by peers (cf. Sivertsen, 2017) may in fact encourage book publishing. Indeed, the shares of monographs and book chapters seem to be creeping up in Flanders, probably thanks to initiatives such as the GPRC-label and the formal recognition of series that apply peer review. Under such circumstances, the formal requirements of a PRFS may turn out to be beneficial for book publishing in the longer term, as the demand by (younger) scholars for transparent peer review of book publications results in systems that reconcile the epistemic contexts of scholars with the needs of scholars in view of formal and informal evaluation contexts and high quality publishing. Indeed, both publishers and scholars stand to win from further formalizing the peer review processes of books.

\section{Conclusion}

The data presented in this paper show that book publications are and remain vital for the SSH. Hence, book publications should also be taken into account fully in research evaluation. Indeed, this paper shows that in countries that have implemented formal PRFS 
the share of book publications tends to evolve gradually over time, mostly with only very slight year-to-year variation, both downward and upward. These observations for Flanders (Belgium), Finland, Norway, Poland and Slovenia contradict generalizations that PRFS are at odds with book publishing.

\section{References}

Aagaard, K., Bloch, C. and Schneider, J.W. (2015), "Impacts of performance-based research funding systems: the case of the Norwegian Publication Indicator", Research Evaluation, Vol. 24 No. 2, pp. 106-117.

Basili, C. and Lanzillo, L. (2018), "Research quality criteria in the evaluation of books", in Bonaccorsi, A. (Ed.), The Evaluation of Research in Social Sciences and Humanities. Lessons from the Italian Experience, Springer, Cham, pp. 159-184, available at: https://doi.org/10.1007/978-3-31968554-0_7

Bonaccorsi, A. (2018), "Towards an epistemic approach to evaluation in SSH", in Bonaccorsi, A. (Ed.), The Evaluation of Research in Social Sciences and Humanities: Lessons from the Italian Experience, Springer, Cham, pp. 1-29, available at: https://doi.org/10.1007/978-3-319-68554-0_1

Chang, R. (1997), "Incomparability and practical reason", $\mathrm{PhD}$ thesis, University of Oxford, Oxford.

Chodorow, S. (1999), "The pace of scholarship, the scholarly career, and the monograph: the once and future monograph", in Case, M.C. and Case, M.M. (Eds), The Specialized Scholarly Monograph in Crisis, Or, How Can I Get Tenure If You Won't Publish My Book?, Association of Research Libraries, Washington, DC, available at: http://old.arl.org/resources/pubs/specscholmono/ Chodorow.shtml

Cronin, B. (2003), "Scholarly communication and epistemic cultures", New Review of Academic Librarianship, Vol. 9 No. 1, pp. 1-24, available at: https://doi.org/10.1080/13614530410001692004

Cronin, B. and La Barre, K. (2004), "Mickey mouse and Milton: book publishing in the humanities", Learned Publishing, Vol. 17 No. 2, pp. 85-98.

Crossik, G. (2016), "Monographs and open access", Insights, Vol. 29 No. 1, pp. 14-19, available at: https:// doi.org/10.1629/uksg.280

Donner, P. (2018), "Supplementing citation to rarely cited works with citations from Google Books", the case of German PhD theses, STI 2018, Leiden.

Edwards, L. (2012), "Editing academic books in the humanities and social sciences: maximizing impact for efforts", Journal of Scholarly Publishing, Vol. 44 No. 1, pp. 61-74, available at: https:// doi.org/10.3138/jsp.44.1.61

Elliot, M.A. (2015), "The future of the monograph in the digital era: a report to the Andrew W. Mellon foundation", The Journal of Electronic Publishing, Vol. 18 No. 4, available at: https://oi.org/10. 3998/3336451.0018.407

Engels, T.C.E., Ossenblok, T.L.B. and Spruyt, E.H.J. (2012), "Changing publication patterns in the social sciences and humanities, 2000-2009”, Scientometrics, Vol. 93 No. 2, pp. 373-390, available at: https://doi.org/10.1007/s11192-012-0680-2

Gimenez-Toledo, E., Manana-Rodriguez, J., Engels, T.C.E., Guns, R., Kulczycki, E., Ochsner, M., Pölönen, J., Sivertsen, G. and Zuccala, A.A. (2018), "Taking scholarly books into account, part II”, Scientometrics, forthcoming.

Gimenez-Toledo, E., Manana-Rodriguez, J., Engels, T.C.E., Ingwersen, P., Pölönen, J., Sivertsen, G., Verleysen, F. and Zuccala, A.A. (2016), "Taking scholarly books into account: current developments in five European countries", Scientometrics, Vol. 107 No. 2, pp. 685-699.

Guns, R. (2018), “Concentration of academic book publishers”, STI 2018, Leiden.

Guns, R., Sīle, L., Eykens, J., Verleysen, F.T. and Engels, T.C.E. (2018), "A comparison of cognitive and organizational classification of publications in the social sciences and humanities", Scientometrics, Vol. 116 No. 2, pp. 1093-1111, available at: https://doi.org/10.1007/ s11192-018-2775-x 
Hammarfelt, B. (2017), "Recognition and reward in the academy: valuing publication oeuvres in biomedicine, economics and history", Aslib Journal of Information Management, Vol. 69 No. 5 , pp. 607-623, available at: https://doi.org/10.1108/AJIM-01-2017-0006

Hammarfelt, B. and de Rijcke, S. (2015), "Accountability in context: effects of research evaluation systems on publication practices, disciplinary norms, and individual working routines in the faculty of Arts at Uppsala University", Research Evaluation, Vol. 24 No. 1, pp. 63-77, available at: https://doi.org/10.1093/reseval/rvu029

Harnad, S. (1986), "On reviewing (and publishing in) edited interdisciplinary volumes”, Contemporary Psychology, Vol. 31, p. 390.

Hicks, D. (2004), "The four literatures of social science", in Moed, H.F., Glänzel, W. and Schmoch, U. (Eds), Handbook of Quantitative Science and Technology Research, Kluwer Academic Publishers, Dordrecht, pp. 473-496.

Jones, M. (2008), Feast: Why Humans Share Food, Oxford University Press, Oxford.

Joseph, R.P. (2015), "Higher education book publishing, from print to digital: a review of the literature", Publishing Research Quarterly, Vol. 31 No. 4, pp. 264-274, available at: https://doi.org/10.1007/s12 109-015-9429-0

Kulczycki, E. (2017), “Assessing publications through a bibliometric indicator: the case of comprehensive evaluation of scientific units in Poland", Research Evaluation, Vol. 45 No. 1, pp. 41-52, available at: https://doi.org/10.1093/reseval/rvw023

Kulczycki, E. (2018), "The diversity of monographs: changing landscape of book evaluation in Poland", Aslib Journal of Information Management.

Kulczycki, E., Engels, T.C.E., Pölönen, J., Bruun, K., Dušková, M., Guns, R., Nowotniak, R., Petr, M., Sivertsen, G., Istenič Starčič, A. and Zuccala, A. (2018), "Publication patterns in the social sciences and humanities: the evidence from eight European countries", Scientometrics, Vol. 116 No. 1, pp. 463-486, available at: https://doi.org/10.1007/s11192-018-2711-0

Larivière, V., Haustein, S. and Mongeon, P. (2015), "The oligopoly of academic publishers in the digital era”, PloS One, Vol. 10 No. 6, available at: https://doi.org/10.1371/journal.pone.0127502

Lewandowska, K. and Miroslaw Stano, P. (2018), "Evaluation of research in the arts : evidence from Poland", Research Evaluation, available at: https://doi.org/10.1093/reseval/rvy021

Martin, K. and Quan-Haase, A. (2013), "Are e-books replacing print books? Tradition, serendipity, and opportunity in the adoption and use of e-books for historical research and teaching", Journal of the American Society for Information Science and Technology, Vol. 64 No. 5, pp. 1016-1028, available at: https://doi.org/10.1002/asi.22801

Nederman, C.J. (2005), "Herding cats: the view from the volume and series editor", Journal of Scholarly Publishing, Vol. 36 No. 4, pp. 221-228.

Nordforsk (2018), "Comparing research in social sciences and the humanities in the Nordic countries: an explorative study", available at: www.nordforsk.org/en/publications/publications_container/ comparingresearch-in-social-sciences-and-the-humanities-in-the-nordic-countries-an-explorativestudy/download (accessed January 13, 2018).

Organisation for Economic Co-operation and Development (2015), Frascati Manual 2015: Guidelines for Collecting and Reporting Data on Research and Experimental Development, OECD Publishing, Paris, available at: https://doi.org/10.1787/9789264239012-en

Pihlström, S. (2014), "Academic publishing and interdisciplinarity: Finnish experiences", Human Affairs, Vol. 24 No. 1, pp. 40-47.

Puuska, H.-M. (2011), "Julkaisemisen muodot ja niiden kehitys eri tieteenaloilla", in Kaukonen, E., Himanen, L., Muhonen, R., Puuska, H.-M., Talola, N. and Auranen, O. (Eds), Tutkimuksen tuottavuuden kehitys Suomen yliopistoissa, Opetusministeriö, Helsinki, pp. 16-34, available at: $\mathrm{http}: / / j u l k a i s u t$.valtioneuvosto.fi/bitstream/handle/10024/75459/okm02.pdf?sequence $=1 \&$ isAllowed $=\mathrm{y}$ 
Puuska, H.-M. (2014), "Scholarly publishing patterns in Finland: a comparison of disciplinary groups", $\mathrm{PhD}$ thesis, University of Tampere, Tampere.

Slovenia National (2015), "National strategy of open access to scientific publications and research data in Slovenia 2015-2020", Government of the Republic of Slovenia, Ljubljana, available at: www. mizs.gov.si/fileadmin/mizs.gov.si/pageuploads/Znanost/doc/Zakonodaja/Strategije/National_ strategy_for_open_access_21._9._2015.pdf (accessed March 8, 2018).

Sīle, L., Guns, R., Sivertsen, G. and Engels, T.C.E. (2017), European Databases and Repositories for Social Sciences and Humanities Research Output, ECOOM \& ENRESSH, Antwerp, available at: https://doi.org/10.6084/m9.figshare.5172322

Sīle, L., Pölönen, J., Sivertsen, G., Guns, R., Engels, T.C.E., Arefiev, P., Dušková, M., Faurbæk, L., Holl, A., Kulczycki, E., Macan, B., Nelhans, G., Petr, M., Pisk, M., Soós, S., Stojanovski, J., Stone, A., Šušol, J. and Teitelbaum, R. (2018), "Comprehensiveness of national bibliographic databases for social sciences and humanities: findings from a European survey", Research Evaluation, rvy016, available at: https://doi.org/10.1093/reseval/rvy016

Sivertsen, G. (2016), "Patterns of internationalization and criteria for research assessment in the social sciences and humanities", Scientometrics, Vol. 107 No. 2, pp. 357-368.

Sivertsen, G. (2017), "Unique, but still best practice? The research excellence framework (REF) from an international perspective", Palgrave Communications, Vol. 3, Article No. 17078, available at: https://doi.org/10.1057/palcomms.2017.78

Sivula, A., Suominen, J. and Reunanen, M. (2015), “A1 alkuperäisartikkeli tieteellisessä aikakauslehdessä”, Uusien julkaisukäytänteiden omaksuminen ihmistieteissä 2000-luvulla. Kasvatus \& Aika, Vol. 9 No. 3, pp. 149-171.

Sorčan, S., Demšar, F. and Valenci, T. (2008), Znanstveno raziskovanje v Sloveniji, Javna agencija za raziskovalno dejavnost Republike Slovenije, Ljubljana.

Thompson, J.B. (2005), Books in the Digital Age: The Transformation of Academic and Higher Education Publishing in Britain and the United States, Polity, Cambridge.

Thompson, J.W. (2002), "The death of the scholarly monograph in the humanities? Citation patterns in literary scholarship", Libri, Vol. 52 No. 3, pp. 121-136.

Townsend, R.B. (2003), "History and the future of scholarly publishing, field does better than most in getting books published, but problems loom", Perspectives, October, pp. 32-37.

Verleysen, F.T. and Engels, T.C.E. (2012), "Historical publications at Flemish universities (2000-2009)", Journal of Belgian History/Belgisch Tijdschrift voor Nieuwste Geschiedenis, Vol. 42 No. 4, pp. 110-143, available at: www.journalbelgianhistory.be/en/system/files/article_ pdf/007_Verleysen_Engels_2012_4.pdf

Verleysen, F.T. and Engels, T.C.E. (2013), "A label for peer-reviewed books", Journal of the American Society for Information Science and Technology, Vol. 64 No. 2, pp. 428-430.

Verleysen, F.T. and Engels, T.C.E. (2014), "Internationalization of peer reviewed and non-peer reviewed book publications in the social sciences and humanities", Scientometrics, Vol. 101 No. 2, pp. 1431-1444.

Verleysen, F.T. and Ossenblok, T.L.B. (2017), "Profiles of monograph authors in the social sciences and humanities: an analysis of productivity, career stage, co-authorship, disciplinary affiliation and gender, based on a regional bibliographic database", Scientometrics, Vol. 111 No. 3, pp. 1673-1683, available at: https://doi.org/10.1007/S11192-017-2312-3

Verleysen, F.T. and Weeren, A. (2016), "Mapping diversity of publication patterns in the social sciences and humanities: an approach making use of fuzzy cluster analysis", Journal of Data and Information Science, Vol. 1 No. 4, pp. 33-59, available at: https://doi.org/10.20309/ JDIS.201624

Williams, G., Basso, A., Galleron, I. and Lippiello, T. (2018), "More, less or better: the problem of evaluating books in SSH research", in Bonaccorsi, A. (Ed.), The Evaluation of Research in Social Sciences and Humanities: Lessons from the Italian Experience, Springer, Cham, pp. 1-29, available at: https://doi.org/10.1007/978-3-319-68554-0_6 
Williams, P., Stevenson, I., Nicholas, D., Watkinson, A. and Rowlands, I. (2009), "The role and future of the monograph in arts \& humanities research", ASLIB Proceedings, Vol. 61 No. 1, pp. 67-82, available at: https://doi.org/10.1108/00012530910932294

Wolfe, A. (1990), "Books vs. articles: two ways of publishing sociology", Sociological forum, Vol. 5 No. 3, pp. $477-489$.

Zuccala, A.A., Verleysen, F.T., Cornacchia, R. and Engels, T.C.E. (2015), "Altmetrics for the humanities: comparing goodreads reader ratings with citations to history books", Aslib Journal of Information Management, Vol. 67 No. 3, pp. 320-336, available at: https://doi.org/10.1108/AJIM-11-2014-0152

\section{Corresponding author}

Tim C.E. Engels can be contacted at: Tim.Engels@uantwerpen.be 